\title{
Shouts from the Sidelines: Can Coaching Be Taught?
}

\author{
ZOLTÁN BARACSKAI ${ }^{1}$
}

\begin{abstract}
Twenty years ago, when I asked five or six MBA students whether they would like to be freelancers, all of them said yes. As years passed, fewer and fewer responded with a yes. Today the situation is completely reversed - everybody answers with a no. They say future is uncertain. This era rejects the idea of not belonging anywhere. Maybe it is so. In this essay I will examine whether coaching can be taught. In order for something to be teachable, the teacher, the learner and the content are essential. If any of these is missing, teaching becomes impossible. This where the message of the essay stems from: The coach shouts fresh knowledge from the Sidelines to the eager coachee. Well, one can write about the identity of the characters and the process, but this will not result in the fact that the steps to becoming a professional coach can be identified. People who are less talented have to learn/practice more. And there are those who are gifted in something and thus need to learn / practice less. Many students, who were somewhat informed, had difficulty accepting my telling them that they came to that school to see that a different approach is also possible.
\end{abstract}

\section{Keywords}

Conceptual model, contextualization, applicable knowledge

„If you look at economics textbooks, you will learn that homo economicus can think like Albert Einstein, store as much memory as ibm's Big Blue, and exercise the willpower of Mahatma Gandhi. Really. But the folks that we know are not like that." (Richard Thaler)

1. Corresponding author: Baracskai Zoltán, email: baracskai.zoltan@sze.hu; Széchenyi University Győr, Hungary 